\title{
KERAGAMAN GENOTIP DAN JARAK GENETIK SAPI MADURA BERDASARKAN Restriction Fragment Length Polymorphism-DNA (RFLP-DNA)
}

\section{GENOTYPE VARIANCE AND GENETIC DISTANCE OF MADURA CATTLE BASED ON THE Restriction Fragment Length Polymorphism-DNA (RFLP-DNA)}

\author{
Marleny Leasa ${ }^{1 *}$ dan Rony Marsyal Kunda ${ }^{2}$ \\ ${ }^{1}$ Fakultas Keguruan Ilmu Pendidikan, Universitas Pattimura, J. Dr Tamaela, Ambon, 97118 \\ ${ }^{2}$ Alumnus Pascasarjana Sain Veteriner, Fakultas Kedokteran Hewan, Universitas Gadjah Mada, Jl. Fauna No. 2, \\ Bulaksumur, Yogyakarta, 55281
}

\section{INTISARI}

Penelitian ini bertujuan untuk mengetahui variasi genotip dan jarak genetik sapi Madura di Kabupaten Sampang dan Balai Besar Inseminasi Buatan (BBIB) Singosari berdasarkan teknik RFLP. Digesti DNA genom dengan enzim EcoRI dan Pst menghasilkan fragmen DNA dengan ukuran yang bervariasi baik pada induk, pedet, dan pejantan unggul dengan kisaran antara 10000 bp sampai $980 \mathrm{bp}$ dan 10000 bp sampai $1250 \mathrm{bp}$. Analisis MVSP1 dengan metode UPGMA untuk jarak genetik ditemukan bahwa sampel sapi Madura berada dalam 2 cluster dan 1 outgroup. Persentase jarak genetik berada pada rentangan 0 sampai $25 \%$.

(Kata kunci: Variasi genotip, Jarak genetik, Sapi Madura, RFLP)

\section{ABSTRACT}

The study aimed was to find the genotype variance and genetic distance of Madura cattle in Sampang and BBIB Singosari districts based on RFLP technique. DNA genome was digested by EcoRI and PstI which produce DNA fragment with variety sizes in dam, calves and superior bull. Those DNA fragment sizes range from $10000 \mathrm{bp}$ to $980 \mathrm{bp}$ and $10000 \mathrm{bp}$ to $1250 \mathrm{bp}$. MVSP I analysis with UPGMA method for the genetic distance found that the subject of Madura cattle put in 2 cluster and 1 out-group. The presentation of genetic distance ranged from 0 to $25 \%$.

(Key words: Genotype variance, Ggenetic distance, Madura cattle, RFLP)

\section{Pendahuluan}

Sapi potong lokal yang dikembangkan dalam usaha peternakan di tanah air adalah sapi Bali, sapi Madura, sapi Peranakan Ongole, dan sapi campuran. Sapi-sapi tersebut tercatat sebagai sapi potong asli Indonesia (Siregar, 2008). Menurut Gunawan (1993), sapi Madura diduga merupakan hasil persilangan antara sapi Bali (Bos sondaicus) dengan sapi Zebu (Bos indicus). Sapi Madura merupakan salah satu bangsa sapi yang dipertahankan kemurniannya di pulau Madura dan pulaupulau kecil di sekitarnya. Sapi yang berpunuk ini dikenal sebagai sapi Jawa asli dengan warna kuning hingga merah bata (Zainal, 2002; Noor, 2008).

Wijono dan Setiadi (2004) melaporkan bahwa saat ini sapi Madura mengalami degradasi produktivitas. Degradasi produktivitas terjadi karena seleksi negatif dan inbreeding. Seleksi negatif discbabkan oleh pemotongan sapi produktif

\footnotetext{
* Korespondensi (corresponding author):

Telp. +6285781034048

E-mail: marleny_leasa@yahoo.com
}

atau tampilan yang baik oleh peternak yang akhirnya digunakan sebagai standar pasar ternak sapi potong. Inbreeding terjadi karena pulau Madura merupakan wilayah tertutup untuk sapi potong lain, akibatnya sapi Madura yang ditemukan hanya yang dalam ukuran kecil saja. Pedersen $e t$ al. (2008) menyebutkan bahwa inbreeding dapat mengurangi kesempatan terekspresinya karakterkarakter yang bersifat heterozigot, akibatnya terjadi peningkatan jumlah abnormalitas, penurunan fertilitas, dan peningkatan kematian ternak. Kondisi yang demikian berdampak pada penurunan mutu genetik sapi Madura, apalagi populasinya di Indonesia yang hanya mencapai $12 \%$ (Zainal, 2002).

Peningkatan produktivitas sapi Madura perlu dilakukan dengan jalan memperbaiki mutu genetiknya. Teknologi reproduksi yang telah dikembangkan dalam upaya untuk mengatasi permasalahan ini antara lain melalui inseminasi buatan yang melibatkan sentra peternakan di kabupaten Sampang dan pihak BBIB Singosari. Implementasi inseminasi buatan pada sapi Madura telah berlangsung sejak tahun 1983. 
Sehubungan dengan peningkatan produktivitas sapi Madura melalui upaya pembibitan dan perbaikan mutu genetik pejantan, maka perlu dilakukan identifikasi variasi genetik. Upaya ini difokuskan kepada induk, pejantan unggul, dan pedet sapi Madura yang terlibat dalam inseminasi buatan. Pelaksanaan identifikasi variasi genetik dimaksudkan untuk mengetahui seberapa besar aliran potensi genetik dari induk dan pejantan unggul kepada keturunannya. Rahayu et al. (2006) mengemukakan bahwa untuk identifikasi variasi genetik dapat dilakukan kajian molekuler melalui analisis isoenzim dan DNA.

Analisis DNA dapat dilakukan dengan mengikuti beberapa teknik yang didasarkan pada variasi genotip. Melalui analisis variasi genotip juga dapat diungkapkan jarak genetik antar individu dalam satu spesies (Gesriantuti et al., 2002). Restriction Fragment Lenght Polymorphism (RFLP) merupakan salah satu teknik analisis DNA yang dimanfaatkan untuk mendeteksi variasi genotip dan jarak genetik (Saryanto, 2003; Fries dan Ruvinsky, 1999). Fatchiyah et al. (2007) dan Aulanni'am (2004) menegaskan bahwa RFLP merupakan salah satu teknik molekuler yang tingkat akurasinya sangat tinggi karena dapat mengidentifikasi sekuensekuen DNA pada genom organisme, mudah dilakukan di laboratorium, bersifat kodominan sehingga dapat juga mendeteksi adanya heterosigositas. RFLP berdasar pada homologi sekuens sehingga cocok untuk membuat analisis jarak genetik antar individu dalam satu spesies. Namun di sisi lain, RFLP membutuhkan DNA dengan kemurnian yang tinggi dalam jumlah banyak (Vasconcellos et al., 2003).

Dari penelitian-penelitian sebelumnya diketahui bahwa kajian secara ilmiah terhadap sumber genetik sapi Madura di BBIB Singosari dan di kabupaten Sampang masih belum banyak dilakukan (Rahadi, 2005; Mudawamah, 2009). Hal ini menandakan bahwa sumber genetik sapi Madura di kedua tempat belum dideskripsikan dengan jelas dan spesifikasi. Di samping itu, gambaran potensi genetik atau sifat unggul yang diwariskan oleh pejantan dapat dianalisis untuk mengetahui keberhasilan inseminasi buatan yang telah berlangsung sekian lama. Dengan demikian tujuan penelitian ini adalah untuk mengetahui komparasi variasi genotip dan jarak genetik sapi Madura antara induk, pedet di kabupaten Sampang dengan pejantan unggul di BBIB Singosari berdasarkan RFLP oleh enzim EcoRI dan PstI.

\section{Materi dan Metode}

Sampel dalam penelitian ini adalah 10 ekor sapi, yang terdiri dari 4 ekor induk dan 4 ekor pedet sapi Madura, yang pengambilannya secara purposive sampling di Kabupaten Sampang Pulau Madura dan 2 pejantan unggul sapi Madura di BBIB Singosari. Analisis DNA dilakukan di Laboratorium Biologi Molekuler Universitas Brawijaya Malang. Untuk keperluan analisis DNA, darah diambil dari vena jugularis di leher dengan venoject yang sudah diisi dengan EDTA. Isolasi DNA mengikuti metode salting out (Fatchiyah et al., 2007). Hasil isolasi DNA total disimpan pada suhu $-20^{\circ} \mathrm{C}$. Setelah itu dilanjutkan dengan elektroforesis DNA total dan estimasi kemurnian dan konsentrasi DNA.

Langkah selanjutnya adalah digesti DNA oleh enzim restriksi EcoRI dan PstI. Caranya yaitu ke dalam tabung eppendorf dimasukkan $3 \mu$ DNA ditambah dengan masing-masing $5,5 \mu \mathrm{l} \mathrm{dH}_{2} \mathrm{O}$, buffer enzim $1 \mu \mathrm{l}$, dan $0,5 \mu \mathrm{l}$ enzim, kemudian diinkubasi pada suhu $37^{\circ} \mathrm{C}$ selama overnight, Pengamatan hasil fragmentasi dilakukan dengan cara elektroforesis gel agarosa $1,5 \%$.

Analisis data dilakukan secara deskriptif. Fragmen-fragmen DNA yang muncul dikonfirmasi dengan DNA marker lalu diberi skor. Menurut Aulanni'am (2004), pemberian skor pada fragmen DNA adalah menggunakan angka 0 jika tidak ada pemotongan dan angka 1 jika ada pemotongan dengan tebal fragmen $<0,5 \mathrm{~mm}$. Data ukuran pasang basa fragmen DNA kemudian dianalisis jarak genetiknya memanfaatkan software MVSP1 (Multi Variate Statistic Package).

\section{Hasil dan Pembahasan}

Gambar 1 menunjukkan bahwa pada sampel induk dan pedet (F1) sapi Madura, enzim restriksi EcoRI mengenali 27 fragmen restriksi di sepanjang DNA genom. Secara umum, persentase kesamaan fragmen induk dan pedet berdasarkan hasil digesti enzim ini berkisar antara $37,5 \%$ sampai $62,5 \%$. Hasil RFLP terhadap sejumlah fragmen DNA atas dasar ada atau tidaknya fragmen yang dipotong oleh enzim restriksi EcoRI pada sampel dimaksud ditunjukkan pada Tabel 1 .

Variasi genotip DNA induk dan pedet (F1) sapi Madura di kabupaten Sampang hasil potongan oleh enzim restriksi Pst, disajikan pada Gambar 2. Gambar 2 menunjukkan bahwa digesti enzim restriksi Pst I menghasilkan 25 fragmen. Persentase kesamaan fragmen DNA antara induk dengan pedet berada pada kisaran $37,5 \%$ sampai $75 \%$. Hasil RFLP tersaji pada Tabel 2.

Variasi genotip pejantan unggul Sapi Madura di BBIB Singosari hasil potongan oleh enzim restriksi EcoRI dan PstI, melalui hasil elektroforesis gel agarosa dan zimogram ditunjukkan pada Gambar 3. Gambar 3 menunjukkan bahwa pada 


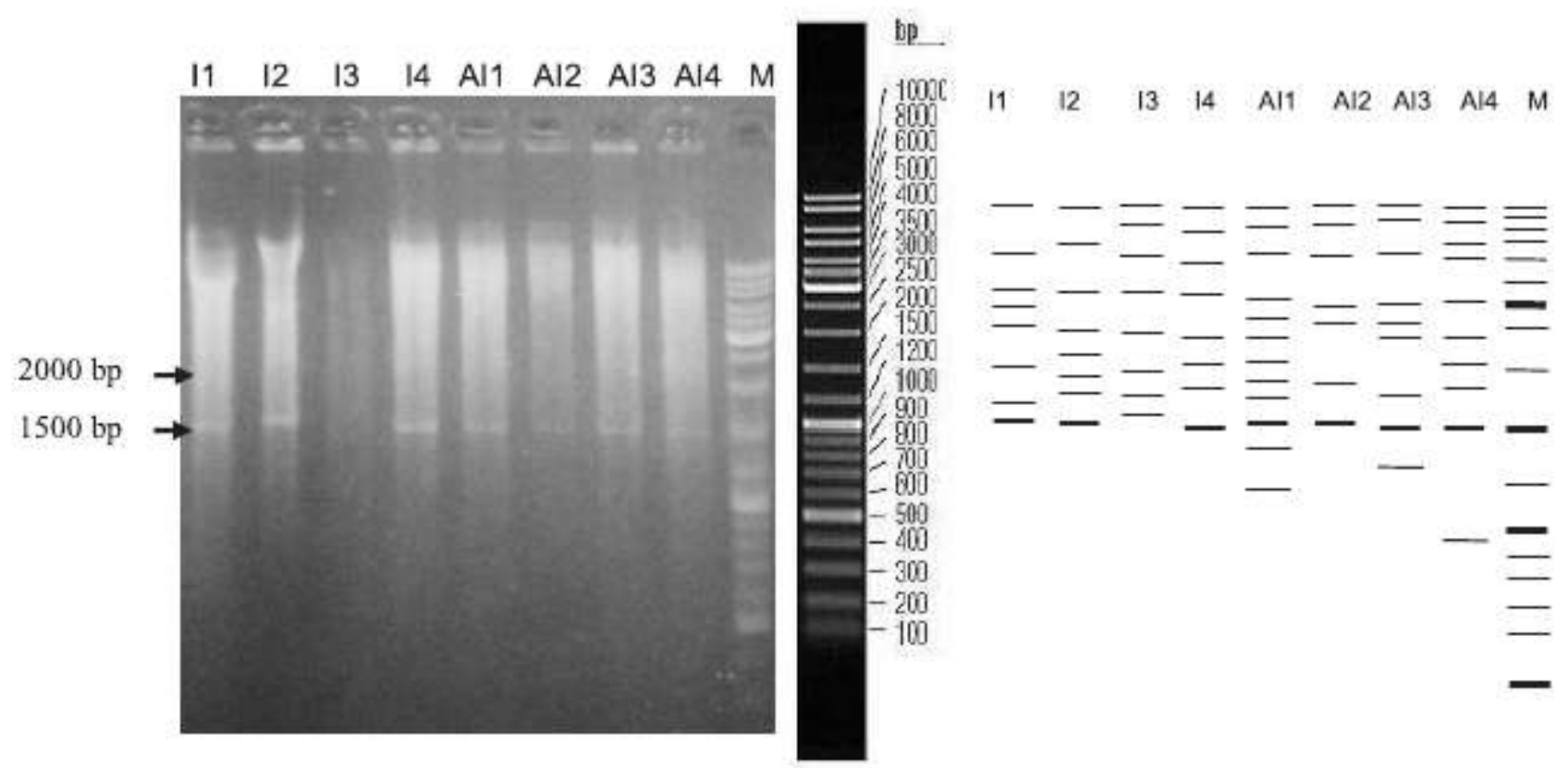

Keterangan: $\mathrm{I} 1-\mathrm{I} 4=$ induk sapi Madura, $\mathrm{AI} 1-\mathrm{AI} 4=$ pedet sapi Madura, $\mathrm{M}=$ marker DNA $(I 1-14=$ dam, $A I 1-A 14=$ calves, $M=D N A$ marker).

Gambar 1. Hasil elektroforesis gel agarosa 1,5\% dan zimogram hasil pemotongan DNA induk dan pedet sapi Madura oleh enzim EcoRI (the result of Agarosa gel electroforesis $1.5 \%$ and zimogram of DNA fragment of dam and calves Madura cattles digested by EcoRl enzyme).

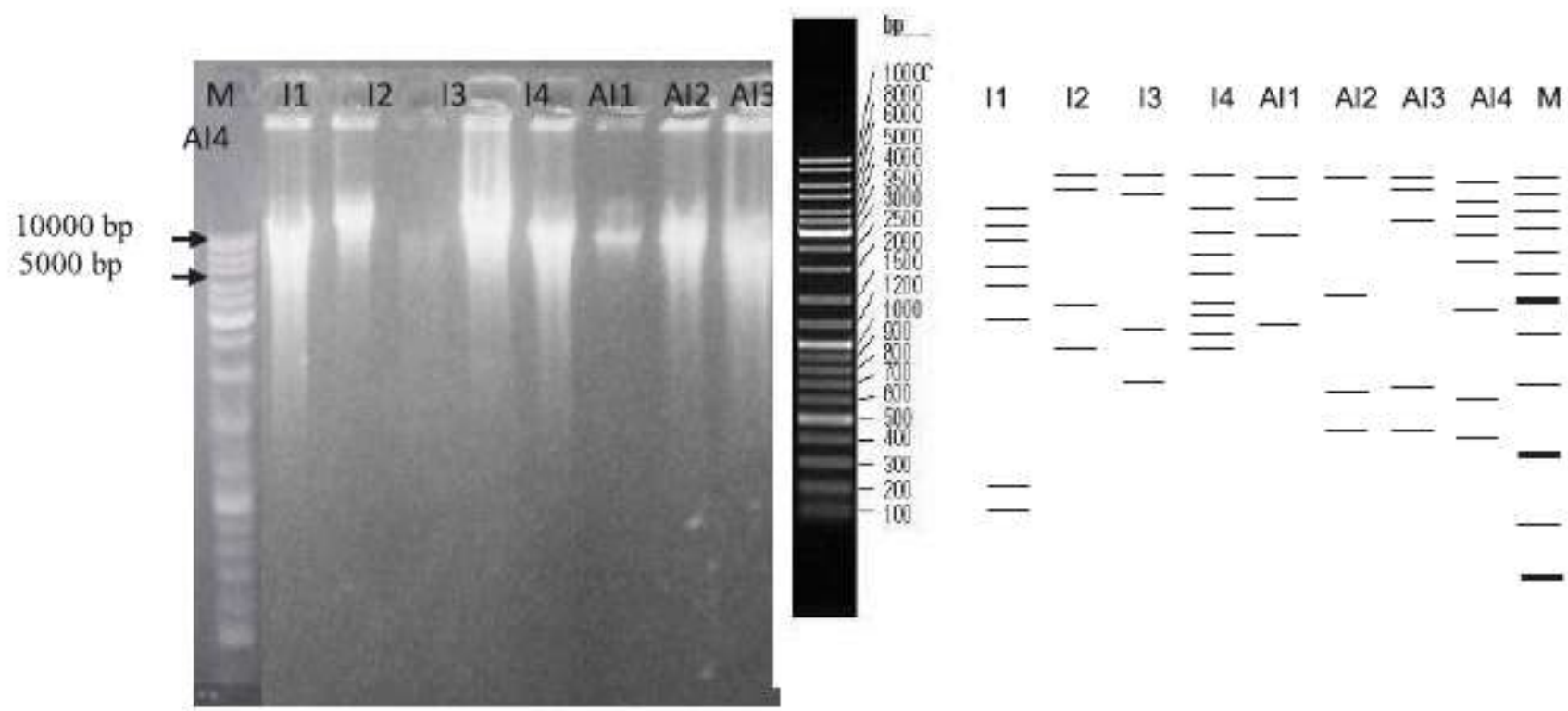

Keterangan: $11-14=$ induk sapi Madura, All-AI4 = pedet sapi Madura, $\mathrm{M}=$ marker DNA $(I I-14=$ dam, $A I I-A I 4=$ calves, $M=D N A$ marker).

Gambar 2. Hasil elektroforesis gel agarosa 1,5\% dan zimogram hasil pemotongan DNA pada induk dan pedet sapi Madura oleh enzim PstI (the result of agarosa electroforesis gel 1.5\% and zimogram of DNA fragment of dam and calves Madura cattles by Pstl enzyme).

sampel pejantan unggul sapi Madura, enzim restriksi EcoRI mengenal 16 fragmen. Enzim restriksi PstI mengenal 6 fragmen pemotongan DNA yang tersebar di sepanjang genom total. Fragmen DNA yang dimiliki oleh kedua pejantan unggul ini adalah fragmen $3500 \mathrm{bp}$ dan $10000 \mathrm{bp}$ atau persentase kesamaan fragmen sebesar $33 \%$. Fragmen DNA hasil RFLP tersaji pada Tabel 3.

Dendogram jarak genetik antara induk, pedet, dan pejantan unggul berdasarkan pola potongan 
Tabel 1. Hasil RFLP atas dasar ada atau tidak ada fragmen DNA yang dipotong oleh enzim restriksi EcoRI pada induk dan pedet sapi Madura di Kabupaten Sampang (the result of RFLP based on the existence and not existence of DNA fragment which was digested by EcoRI enzyme of dam and calves Madura cattle at Sampang District)

\begin{tabular}{ccccccccc}
\hline DNA & \multicolumn{7}{c}{ Sampel (sample) } & \\
(bp) & I1 & I2 & I3 & I4 & AII & AI2 & AI3 & AI4 \\
\hline 10000 & 1 & 1 & 1 & 1 & 1 & 1 & 1 & 1 \\
8000 & 0 & 0 & 0 & 0 & 0 & 0 & 1 & 0 \\
7000 & 0 & 0 & 0 & 0 & 0 & 0 & 0 & 1 \\
6000 & 0 & 0 & 1 & 1 & 1 & 1 & 0 & 0 \\
5000 & 0 & 1 & 0 & 0 & 0 & 0 & 0 & 1 \\
4000 & 1 & 0 & 1 & 1 & 1 & 1 & 1 & 1 \\
3300 & 1 & 1 & 1 & 1 & 0 & 0 & 0 & 0 \\
3100 & 0 & 0 & 0 & 0 & 1 & 0 & 0 & 0 \\
3000 & 1 & 0 & 0 & 0 & 0 & 1 & 1 & 1 \\
2750 & 0 & 0 & 0 & 0 & 1 & 0 & 0 & 0 \\
2500 & 1 & 1 & 0 & 0 & 0 & 1 & 1 & 0 \\
2400 & 0 & 0 & 1 & 1 & 1 & 0 & 1 & 1 \\
2200 & 0 & 1 & 0 & 0 & 0 & 0 & 0 & 0 \\
2050 & 0 & 0 & 0 & 1 & 1 & 0 & 0 & 1 \\
2000 & 1 & 0 & 1 & 0 & 0 & 0 & 0 & 0 \\
1950 & 0 & 1 & 0 & 0 & 0 & 0 & 0 & 0 \\
1900 & 0 & 0 & 0 & 0 & 1 & 1 & 0 & 0 \\
1850 & 0 & 0 & 0 & 1 & 0 & 0 & 0 & 0 \\
1800 & 0 & 1 & 1 & 0 & 0 & 0 & 1 & 1 \\
1750 & 0 & 0 & 0 & 0 & 1 & 0 & 0 & 0 \\
1700 & 1 & 0 & 0 & 0 & 0 & 0 & 0 & 0 \\
1600 & 0 & 0 & 1 & 0 & 0 & 0 & 0 & 0 \\
1500 & 1 & 1 & 0 & 1 & 1 & 1 & 1 & 1 \\
1400 & 0 & 0 & 0 & 0 & 1 & 0 & 0 & 0 \\
1300 & 0 & 0 & 0 & 0 & 0 & 0 & 1 & 0 \\
1180 & 0 & 0 & 0 & 0 & 1 & 0 & 0 & 0 \\
980 & 0 & 0 & 0 & 0 & 0 & 0 & 0 & 1 \\
\hline
\end{tabular}

$1=$ Ada fragmen DNA, $0=$ Tidak ada fragmen, II-I4 = induk, AIl-AI4 = pedet ( $I=$ the existence of DNA fragment, 0

$=$ no existence of DNA fragment, $I I-14=$ dam, $A I I-A I 4=$ calves $)$.

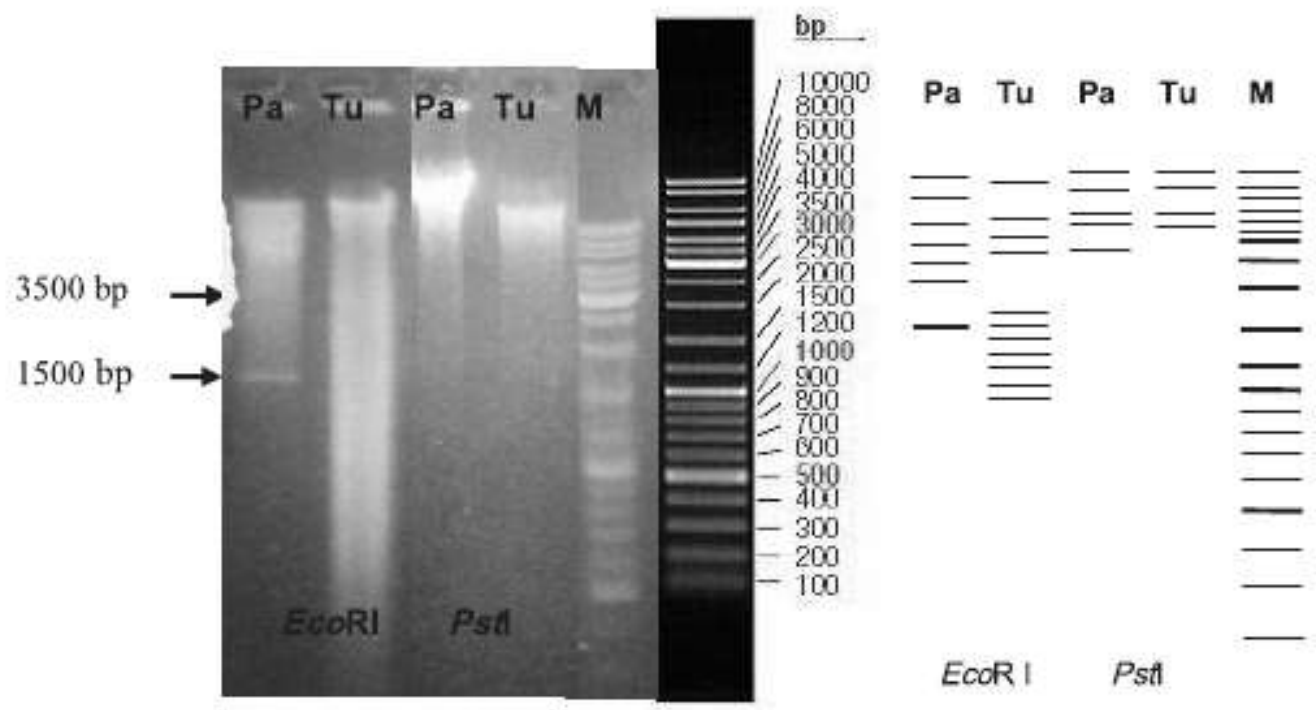

Keterangan: $\mathrm{Pa}=$ Prapanca, $\mathrm{Tu}=$ Tantular, $\mathrm{M}=$ marker $\mathrm{DNA}(\mathrm{Pa}=$ Prapanca, $\mathrm{Tu}=$ Tantular, $\mathrm{M}=\mathrm{DNA}$ marker $)$.

Gambar 3. Hasil elektroforesis gel agorasa 1,5\% dan zimogram hasil pemotongan DNA pejantan unggul sapi Madura oleh enzim EcoRI dan PstI (the result of agarosa electroforesis gel $1.5 \%$ and zimogram as the result of DNA restriction of superior bull by EcoRI and Pstl enzymes). 
Tabel 2. Hasil RFLP atas dasar ada atau tidak ada fragmen DNA yang dipotong oleh enzim restriksi Pst 1 pada induk dan pedet sapi Madura di Kabupaten Sampang (the result of RFLP of dam and calves Madura cattle at Sampang District based on the existence and not existence of DNA fragment which was digested by enzyme restriction Pstl)

\begin{tabular}{|c|c|c|c|c|c|c|c|c|}
\hline \multirow{2}{*}{$\begin{array}{l}\text { DNA } \\
\text { (bp) }\end{array}$} & \multicolumn{8}{|c|}{ Sampel (sample) } \\
\hline & II & 12 & 13 & I4 & AII & $\mathrm{Al} 2$ & $\mathrm{AI} 3$ & $\mathrm{AI} 4$ \\
\hline 10000 & 0 & 0 & 1 & 1 & 1 & 1 & 1 & 1 \\
\hline 8000 & 0 & 1 & 1 & 0 & 0 & 0 & 1 & 0 \\
\hline 7500 & 0 & 0 & 0 & 0 & 1 & 1 & 0 & 1 \\
\hline 7000 & 0 & 0 & 0 & 0 & 0 & 0 & 0 & 0 \\
\hline 6000 & 1 & 0 & 0 & 1 & 1 & 1 & 0 & 1 \\
\hline 5200 & 0 & 0 & 0 & 0 & 0 & 0 & 1 & 0 \\
\hline 5000 & 1 & 0 & 0 & 1 & 1 & 1 & 0 & 1 \\
\hline 4400 & 1 & 0 & 0 & 0 & 0 & 0 & 0 & 0 \\
\hline 4000 & 0 & 0 & 0 & 1 & 0 & 0 & 0 & 0 \\
\hline 3800 & 0 & 0 & 0 & 0 & 0 & 0 & 0 & 1 \\
\hline 3500 & 1 & 0 & 0 & 1 & 0 & 0 & 0 & 0 \\
\hline 3200 & 1 & 0 & 0 & 0 & 0 & 0 & 0 & 0 \\
\hline 3000 & 0 & 1 & 0 & 1 & 0 & 0 & 0 & 0 \\
\hline 2900 & 0 & 0 & 0 & 0 & 0 & 0 & 0 & 1 \\
\hline 2800 & 0 & 0 & 0 & 1 & 0 & 0 & 0 & 0 \\
\hline 2600 & 1 & 0 & 0 & 0 & 1 & 0 & 0 & 0 \\
\hline 2500 & 0 & 0 & 1 & 1 & 0 & 0 & 0 & 0 \\
\hline 2400 & 0 & 1 & 0 & 1 & 0 & 0 & 0 & 0 \\
\hline 2000 & 0 & 0 & 1 & 0 & 0 & 0 & 1 & 0 \\
\hline 1950 & 0 & 0 & 0 & 0 & 0 & 1 & 0 & 0 \\
\hline 1900 & 0 & 0 & 0 & 0 & 0 & 0 & 0 & 1 \\
\hline 1700 & 0 & 0 & 0 & 0 & 0 & 1 & 1 & 0 \\
\hline 1650 & 0 & 0 & 0 & 0 & 0 & 0 & 0 & 1 \\
\hline 1350 & 1 & 0 & 0 & 0 & 0 & 0 & 0 & 0 \\
\hline 1250 & 1 & 0 & 0 & 0 & 0 & 0 & 0 & 0 \\
\hline
\end{tabular}

$1=$ Ada fragmen DNA, 0 = tidak ada fragmen DNA, II-I4 = induk, AIl-AI4 = pedet $(1$ = the existence of DNA fragment, $0=$ no existence of DNA fragment, $I I-I 4=$ dam, AII-AI4 = calves $)$.

DNA hasil restriksi enzim EcoRI ditunjukkan pada Gambar 4. Gambar 4 menunjukkan bahwa sampel dapat dikategorikan menjadi 2 cluster atau kelompok dan 1 outgroup. Nilai similaritas antara cluster I dan II adalah sebesar $63,3 \%$, sedangkan nilai similaritas antara cluster I, II, dengan outgroup adalah $52,2 \%$. Dendogram ini berbeda dengan dendogram jarak genetik berdasarkan hasil restriksi enzim Pst I, walaupun sampel masih dikategorikan menjadi 2 cluster dan 1 outgroup. Nilai similaritas antara cluster I dan II adalah sebesar $65,8 \%$, sedangkan nilai similaritas antara cluster I, II dengan outgroup adalah $57,8 \%$. Dendogram jarak genetik berdasarkan hasil pemotongan DNA genom oleh enzim Pst I ditunjukkan pada Gambar 5.

Hasil penelitian (Tabel 1 dan Tabel 2) memperlihatkan bahwa adanya variasi genotip yang ditandai dengan berbedanya fragmen DNA hasil potongan setiap enzim restriksi pada sampel induk dan pedet di kabupaten Sampang. Hasil analisis DNA dengan teknik RFLP menunjukkan bahwa pada sampel induk dan pedet (F1), enzim restriksi EcoRI mengenal 27 fragmen DNA dengan ukuran antara 980 bp sampai 10000 bp. Enzim restriksi Pst I mengenali 25 fragmen DNA dengan jumlah pasang basa antara 1250 bp sampai $10000 \mathrm{bp}$. Terdapat sejumlah fragmen yang sama dijumpai pada induk dan pedet, tetapi ada juga yang hanya dijumpai pada induk atau pedet. Hal inilah yang menyebabkan bervariasinya persentase kesamaan fragmen DNA antara induk dan pedet. Persentase kesamaan fragmen DNA antara $\mathrm{I} 3$ dan AI3 juga sebesar $75 \%$, karena terdapat 3 fragmen yang dimiliki oleh $\mathrm{I} 3$ dan AI3 yaitu 10000 bp, 8000 bp, dan 2000 bp. Secara umum ditemukan bahwa persentase kesamaan fragmen hasil restriksi dengan dua enzim yang berbeda antara induk dan pedet cukup bervariasi.

Bervariasinya persentase kesamaan fragmen DNA antara induk dan pedet menunjukkan bahwa potensi genetik yang diturunkan dari induk kepada keturunannya juga berbeda. Variasi kesamaan fragmen antara induk dan pedet ini sangat terkait dengan variasi genotip yang dimiliki tiap induk dan pedet. Dengan mengetahui seberapa besar kesamaan fragmen DNA antara induk dan pedet, dapat diasumsikan bahwa fragmen sisanya merupakan warisan dari pejantan unggul (Mudawamah, 2009). 
Beberapa hasil penelitian sebelumnya dengan menggunakan teknik RFLP juga menemukan variasi genotip pada sapi Madura. Hasil penelitian Widayadi (2006) dengan enzim HaeIII pada sapi Madura di Pulau Sapudi menghasilkan sejumlah fragmen DNA dengan ukuran antara 100 bp sampai 400 bp. Senada dengan ini, hasil penelitian Verkaar et al. (2003) pada sapi Madura dengan enzim restriksi $B f a I$ menghasilkan 3 fragmen DNA yaitu $268 \mathrm{bp}, 261 \mathrm{bp}$, dan $97 \mathrm{bp}$. Hasil penelitian tersebut berbeda dengan hasil penelitian Mudawamah (2009) pada induk dan pedet sapi Madura hasil persilangan sapi Limousin-Madura dengan enzim MspI dan AvaII yang masing-masing menghasilkan 11 fragmen dan 8 fragmen DNA.

Hasil penelitian (Tabel 3) menunjukkan adanya variasi genotip yang diketahui melalui pola fragmen DNA hasil potongan yang berbeda pada kedua pejantan unggul. Hasil penelitian Rahadi (2005) pada pejantan sapi Madura di BBIB Singosari dengan teknik RFLP melalui digesti enzim Pst $\mathrm{I}$ dan HindIII juga menemukan hal yang sama. Fragmen DNA yang muncul sebagai hasil digesti enzim PstI adalah $870 \mathrm{bp}, 449 \mathrm{bp}$, dan 257 bp. Sementara dari hasil digesti enzim HindIII didapatkan 4 fragmen DNA 449 bp, 366 bp, 128 bp, dan 114 bp.

Hasil penelitian Mudawamah (2009) pada pejantan unggul sapi Limousin di BBIB Singosari yang saat ini telah banyak disilangkan dengan induk sapi Madura menemukan adanya sejumlah fragmen DNA dengan ukuran yang bervariasi. Meskipun demikian, kisaran ukuran pasang basa hasil restriksi relatif sama. Hal ini berarti bahwa digesti enzim AvalI, MspI, dan XhoI menghasilkan fragmen DNA dengan ukuran antara $200 \mathrm{bp}$ sampai $10000 \mathrm{bp}$.

Tabel 3. Hasil RFLP atas dasar ada atau tidak ada fragmen DNA yang dipotong oleh enzim restriksi EcoRI dan PstI pada pejantan unggul sapi Madura di BBIB Singosari (the result of RFLP of superior bull at BBIB Singosari based on the existence and not existence of DNA fragment which was digested by EcoRI and PstI enzyme restrictions)

\begin{tabular}{ccccc}
\hline & \multicolumn{2}{c}{ Restriksi enzim EcoRI (EcoRI enzyme restriction) } & \multicolumn{2}{c}{ Restriksi enzim PstI (Pstl enzyme restriction) } \\
\cline { 2 - 6 } DNA (bp) & Prapanca & Tantular & Prapanca & Tantular \\
\hline 10000 & 0 & 0 & 1 & 0 \\
9000 & 1 & 0 & 0 & 0 \\
8000 & 0 & 0 & 0 & 1 \\
7000 & 0 & 0 & 0 & 0 \\
6000 & 0 & 1 & 1 & 0 \\
5500 & 0 & 0 & 0 & 0 \\
5000 & 1 & 0 & 0 & 0 \\
4500 & 0 & 0 & 0 & 1 \\
4000 & 0 & 0 & 1 & 0 \\
3700 & 0 & 1 & 0 & 1 \\
3500 & 1 & 0 & 1 & 0 \\
3100 & 0 & 1 & 0 & 0 \\
3000 & 1 & 0 & 0 & 0 \\
2800 & 0 & 0 & 1 & 0 \\
2500 & 0 & 1 & 0 & 0 \\
2400 & 1 & 0 & 0 & 0 \\
2200 & 0 & 0 & 0 & 0 \\
2050 & 1 & 0 & 0 & 0 \\
1900 & 0 & 0 & 0 & 0 \\
1700 & 0 & 1 & 0 & 0 \\
1500 & 1 & 1 & 0 & 0 \\
1400 & 0 & 1 & 0 & 0 \\
1300 & 0 & 1 & 0 & 0 \\
1200 & 0 & 1 & 0 & 0 \\
1080 & 0 & 1 & 0 & 0 \\
1020 & 0 & 0 & 0 & 0 \\
1000 & 0 & 1 & 0 & 0 \\
950 & 0 & 0 & 0 & 0 \\
500 & 0 & 0 & 0 & 0 \\
\hline A & 0 & 0 & 0 & 0 \\
\hline
\end{tabular}

$1=$ Ada fragmen DNA, $0=$ Tidak ada fragmen DNA $(1=$ the existence of DNA fragment, $0=$ no existence of DNA fragment). 
Perbedaan variasi genotip antara induk dan pedet yang berlokasi di kabupaten Sampang dengan pejantan unggul di BBIB Singosari berdasarkan dua indikator utama. Indikator tersebut yaitu jumlah fragmen yang berhasil dipotong oleh masingmasing enzim dan kisaran ukuran pasang basanya. Berbedanya variasi genotip melalui pola fragmen DNA yang muncul pada sampel induk dan pedet dengan pejantan unggul ini disebabkan karena beberapa faktor. Menurut Yuwono (2005), faktor yang paling utama adalah karena setiap individu memiliki serangkaian materi genetik atau sekuens DNA yang berbeda satu dengan lainnya. Sekuens DNA dapat berbeda antara individu satu dengan lainnya, meskipun berada dalam satu spesies. Hal ini mengakibatkan pola potongan fragmen DNA yang berbeda.

Faktor lain yang mendukung perbedaan variasi genotip ini adalah karena masing-masing enzim restriksi memiliki situs-situs restriksi yang

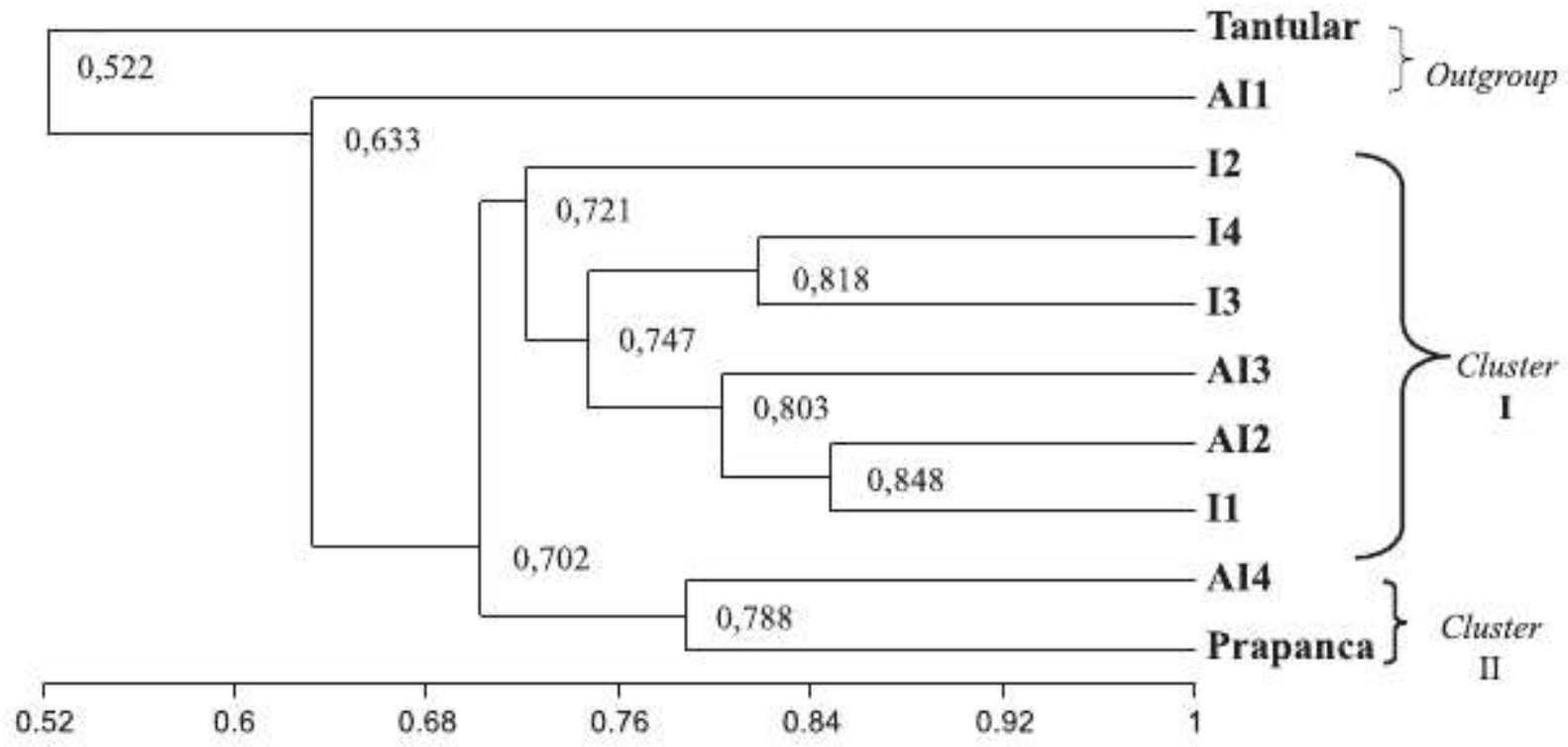

\section{Simple Matching Coefficient}

Gambar 4. Dendogram jarak genetik antara induk, pedet, dan pejantan unggul sapi Madura berdasarkan pola potongan DNA oleh enzim restriksi EcoRI (dendogram of genetic distance among dam, calves, and superior bull based on the DNA fragment by EcoRI restriction enzyme).

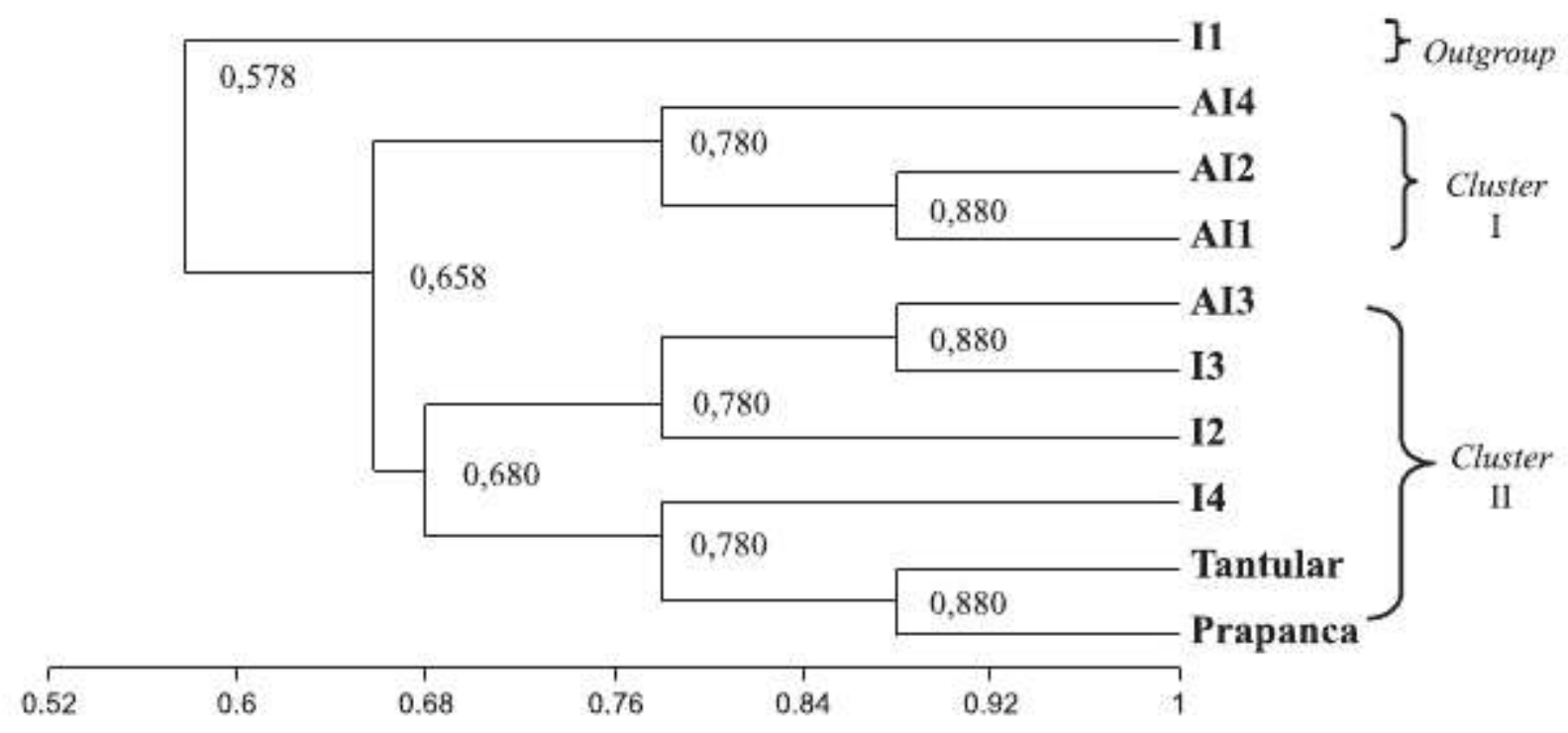

Simple Matching Coefficient

Gambar 5. Dendogram jarak genetik antara induk, pedet, dan pejantan unggul sapi Madura berdasarkan pola potongan DNA oleh enzim restriksi Pst (dendogram of genetic distance among dam, calves, and superior bull based on the DNA fragment by PstI restriction enzyme). 
dapat dikenali di sepanjang DNA genom. Oleh karena itu, setiap enzim mampu mengenali dan memotong sejumlah sekuens tertentu pada DNA genom berdasarkan situs pengenalannya, sehingga menghasilkan jumlah fragmen DNA yang berbeda. Dalam penelitian ini digunakan enzim restriksi EcoRI dan PstI yang menghasilkan variasi pola potongan DNA. Enzim restriksi EcoRI mengenali sekuens pemotongan (restriction site) posisi guanin dan adenin yang menghasilkan sisi potongan stiky end, sementara enzim restriksi PstI mengenali fragmen pemotongan pada basa adenin dan guanin yang menghasilkan sisi potongan stiky end (Klug dan Cummings, 2000; Lodish et al, 2003; Dale dan Park, 2004).

Secara umum dari penelitian ini, ditemukan bahwa berdasarkan hasil digesti enzim restriksi EcoRI dan Pstl dendogram yang dapat dikategorikan dalam 2 cluster dan 1 outgroup. Dimana masing-masing enzim memunculkan polapola fragmen yang berbeda pada setiap sampel, sehingga sampel-sampel yang memiliki jarak genetik dekat atau jauh pada setiap dendogram tidaklah sama. Sebenarnya melalui penelitian ini diharapkan akan ditemukan jarak genetik yang dekat antara setiap induk dengan pedetnya. Namun, dari dendogram jarak genetik melalui digesti enzim EcoRI dan PstI tidak ditemukan jarak genetik yang demikian, kecuali dendogram dengan enzim PstI memperlihatkan bahwa antara $\mathrm{I} 3$ dan $\mathrm{AI} 3$ terdapat hubungan yang begitu erat.

Jarak genetik yang menyimpang dari asumsi dan kenyataan, diduga karena faktor rekombinasi dan mutasi. Menurut Pai (1985), rekombinasi terjadi setiap alih generasi atau keturunan. Corebima (2000) menyatakan bahwa rekombinasi merupakan peristiwa pembentukan suatu asosiasi baru dari molekul-molekul DNA atau kromosom. Dua DNA yang terlibat pada peristiwa rekombinasi umumnya merupakan molekul-molekul berbeda yang mempunyai suatu daerah homolog. Pada daerah homolog itu urut-urutan nukleotida sama atau sekurangkurangnya mirip. Rekombinasi terjadi selama gametogenesis khususnya pada proses meiosis I, sehingga kromosom homolog yang diwariskan dari setiap induk menukarkan beberapa gennya dengan cara pindah silang (crossing over). Pindah silang adalah peristiwa pemutusan dan penyambungan kembali yang diikuti oleh suatu pertukaran resiprok antara kedua kromatid di dalam bentukan bivalent (Corebima, 2000; Rothwell, 1983). Gardner et al. (1991) menjelaskan bahwa pada saat terbentuk 4 kromatid ada kemungkinan terjadi pindah silang, tepatnya pada saat tetrad pasca replikasi. Saat tetrad pasca replikasi kromosom telah mengganda sehingga terbentuk empat kromatid yang masih terikat pada sentromer. Melalui pindah silang, keturunan akan menghasilkan koleksi gamet yang kombinasi kromosomnya jauh berbeda dengan parentalnya.

Mutasi adalah perubahan pada struktur dan molekul materi genetik yang diwariskan pada keturunannya. Materi genetik (gen) terdapat dalam berbagai bentuk sebagai alel yang berlainan, karena mengalami foward mutation, mengurangi frekuensi gen liar, dan back mutation, meningkatkan frekuensi gen liar. Mutasi terjadi secara acak, yang beradaptasi hanya sebagian kecil (Corebima, 2000). Bila suatu mutasi mempunyai nilai ketahanan dan bentuk baru yang diturunkan telah nampak, maka ketahanan, kedewasaan dan reproduksi dari bentuk baru itu tidak bersifat acak lagi (Yuwono, 2005). Namun bila dibandingkan antara rekombinasi dan mutasi, maka jauhnya jarak genetik antara induk dan pedet dalam penelitian ini lebih cenderung disebabkan karena terjadinya rekombinasi. Hal ini sejalan dengan pendapat Supriatno et al. (2007) bahwa mutasi merupakan bahan dasar variasi genetik, namun yang paling memiliki peluang besar sebagai penyebab terjadinya variasi genetik adalah rekombinasi.

\section{Kesimpulan dan Saran}

\section{Kesimpulan}

Hasil RFLP pada induk dan pedet sapi Madura di Kabupaten Sampang dengan menggunakan enzim EcoRI, dan Pst I memiliki variasi genotip dalam ukurannya. Hasil digesti enzim EcoRI menghasilkan 27 fragmen DNA dengan ukuran antara 980 bp sampai 10000 bp. Enzim Pst menghasilkan 25 fragmen DNA dengan ukuran antara 1250 bp sampai 10000 bp. Hasil RFLP pada pejantan unggul sapi Madura di BBIB Singosari dengan menggunakan enzim EcoRI dan PstI juga ditemukan adanya variasi genotip. Enzim EcoRI menghasilkan 16 fragmen DNA dengan ukuran antara 1000 bp sampai $10000 \mathrm{bp}$, sedangkan enzim PstI menghasilkan 6 fragmen DNA dengan ukuran antara 2800 bp sampai 10000 bp. Jarak genetik antara induk dan pedet sapi Madura di kabupaten Sampang dengan pejantan unggul di BBIB Singosari berada pada persentase 0 sampai $25 \%$.

\section{Saran}

Hasil penelitian ini dapat digunakan sebagai dasar penelitian lanjut untuk mengkaji variasi genotip sapi Madura di BBIB Singosari dan di Kabupaten Sampang dengan menggunakan primer tertentu melalui metode PCR-RFLP. Di samping itu, kontes-kontes sapi Madura dalam upaya untuk mendapatkan induk sapi Madura unggul perlu dilakukan sehingga upaya perbaikan produktivitas sapi Madura ke depan akan lebih baik lagi. 


\section{Daftar Pustaka}

Aulanni'am. 2004. Prinsip dan Teknik Analisa Biomolekul. FPUB Press. Malang.

Corebima, A.D. 2000. Genetika Mutasi dan Rekombinasi. Jurusan Biologi FMIPA-UM. Malang.

Dale, J.W. and S. Park. 2004. Molecular Genetics of Bacteria. Jhon Wiley \& Sons, Inc. USA.

Fatchiyah, E.L. Arumingtyas, S. Widyarti, dan S. Rahayu. 2007. Analisa Biologi Molekuler. Brawijaya-Press. Malang.

Fries, R. and A. Ruvinsky (eds). 1999. The Genetics of Cattle. CABI Publishing. London.

Gardner, E.J., M.J. Simmons, and D.P. Snustad. 1991. Principles of Genetic Eight Edition. Jhiseon Wiley \& Sons, Inc. New York.

Gesriantuti, N., J. Situmorang, dan F.A. Sudjadi. 2002. Analisis polimorfisme genetik Anopheles aconitus donitz (Diptera: Culicidae) dari Daerah Istimewa Yogyakarta dan Jawa Tengah dengan RAPD-PCR. Teknosains, 15(1): 139-151.

Gunawan. 1993. Sapi Madura. Kanisius. Yogyakarta,

Klug, W.S, and M.R. Cummings. 2000. Concept of Genetics Sixth Edition. Prentice Hall, Inc. New Jersey.

Lodish, H., A. Berk, P. Matsudaira, C.A. Kaiser, M. Krieger, M.P. Scott, S.L. Zipursky, and J. Darnell. 2003. Molecular Cell Biology, $5^{\text {th }}$ Edition. W.H. Freeman and Company. New York.

Mudawamah. 2009. Evaluasi genetik dengan breeding value dan analisis DNA serta implementasinya oleh para pelaku pembibitan sapi potong hasil persilangan di Perusda UPA Pasuruan dan Sampang Madura (sebuah model pengembangan pembelajaran materi evaluasi genetik dengan kajian meta analisis untuk sapi potong hasil persilangan). Disertasi. PPS UM, Malang.

Noor, R.R. 2008. Genetika Ternak. Penebar Swadaya, Jakarta.

Pai, A.C. 1985. Dasar-dasar Genetika. Terjemahan oleh Apandi, M. 1992. Erlangga, Jakarta.

Pedersen, S.K., N.T. Kristensen, K. Volker Loescheke, O.B. Petersen, J. Duus, Chr.N. Nielsen, and A. Malmenda. 2008. Metabolomic signatures of inbreeding at benign and stressful temperatures in drosophila melanogaster. Genetics, 180: 1233-1243.

Rahadi, S. 2005. Identifikasi genetik sapi lokal Pandaan serta kekerabatannya dengan sapi Bali dan sapi Madura atas dasar analisa RFLP. Tesis. Program Studi Ilmu Ternak PPS Universitas Brawijaya, Malang.

Rahayu, S., S.B. Sumitro, T. Susilowati, dan Soemarno. 2006. Analisis isoenzim untuk mempelajari variasi genetik sapi Bali. Available at http:/journal. discoveryindonesia.com/index.php/hayati/article/view/ 1/1. Accession date: 21 Juni, 2008.

Rothwell, N. 1983. Understanding Genetics. Mc Millan Publishing, Inc. New York.

Saryanto, D. 2003. Melihat keanekaragaman organisme melalui beberapa teknik genetika molckuler. Available at http://library.usu.ac. id/download/fmipa/biologi - dwis. pdf. Accession date: 29 Juni, 2008.

Siregar, S.B. 2008. Penggemukan Sapi. Penebar Swadaya, Jakarta.

Supriatno, S., M. Indrawan, dan R.B. Primarck. 2007. Biologi Konservasi dan Keanekaragaman Hayati Edisi Revisi. Jakarta: Yayasan Obor Indonesia.

Vasconcellos, L.P., D. Tambasco, Talhari, A. Pereira, and L.C. Regitano. 2003. Genetic characterization of Aberdeen Angus cattle using molecular markers. Genetic and Molecular Biology, 26 (2): 133-137.

Verkaar, E.L.C., H. Vervaecke, C. Roden, L.R. Mendoza, M.W. Barwegen, and T. Susilawati. 2003. Paternally inherited markers in bovine hybrid populations. Heredity, Volume 91. Available at http://www.nature.com/hdy/journal/v91/n6/fu $11 / 6800359$ a. Accession date: June 24, 2008.

Wijono, D.S. dan B. Setiadi. 2004. Potensi dan keragaman genetik. Available at http://maduracenter.wordpress.com/2007/07/ 14/potensi-dan-keragaman-sumberdayagenetik. Accession date: 21 Juni, 2008.

Widayadi. 2006. Analisis polimorfisme gen growth hormone dan hubungannya terhadap bobot badan sapi Madura di Pulau Sapudi. Skripsi. Fakultas MIPA-Universitas Brawijaya, Malang.

Yuwono, T. 2005. Biologi Molekular. Erlangga, Jakarta.

Zainal, A. 2002. Penggemukan Sapi Potong. AgroMedia Pustaka, Jakarta. 